\title{
Alterations in Adenosine Triphosphate and Energy Charge in Cultured Endothelial and P388D, Cells after Oxidant Injury
}

\author{
Roger G. Spragg, Daniel B. Hinshaw, Paul A. Hyslop, Ingrid U. Schraufstätter, and Charles G. Cochrane \\ Department of Medicine, University of California, San Diego, California 92103; and Department of Immunology, \\ Scripps Clinic and Research Foundation, La Jolla, California 92037
}

\begin{abstract}
To investigate mechanisms whereby oxidant injury of cells results in cell dysfunction and death, cultured endothelial cells or $\mathbf{P 3 8 8}_{1}$ murine macrophagelike cells were exposed to oxidants including $\mathrm{H}_{2} \mathrm{O}_{2}, \mathrm{O}_{\mathbf{2}}^{-}$(generated by the enzymatic oxidation of xanthine), or to stimulated polymorphonuclear leukocytes (PMN). Although Trypan Blue exclusion was not diminished before $30 \mathrm{~min}$, cellular ATP was found to fall to $<30 \%$ of control values within 3 min of exposure to $5 \mathrm{mM} \mathrm{H}_{2} \mathrm{O}_{2}$. Stimulated PMN plus $\mathrm{P388}_{1}$ caused a 50\% fall in cellular ATP levels. During the first minutes of oxidant injury, total adenylate content of cells fell by $\mathbf{8 5 \%}$. Cellular ADP increased 170\%, AMP increased $\mathbf{9 0 0 \%}$, and an 83\% loss of ATP was accompanied by a stoichiometric increase in IMP and inosine. Calculated energy charge [(ATP + 1/2 AMP)] (ATP + ADP + AMP)] fell from 0.95 to 0.66.

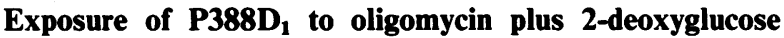
(which inhibit oxidative and glycolytic generation of ATP, respectively) resulted in a rate of ATP fall similar to that induced by $\mathrm{H}_{2} \mathrm{O}_{2}$. In addition, nucleotide alterations induced by exposure to oligomycin plus 2-deoxyglucose were qualitatively similar to those induced by the oxidant. Loss of cell adenylates could not be explained by arrest of de novo purine synthesis or increased ATP consumption by the $\mathrm{Na}^{+}-\mathrm{K}^{+}$ATPase or the mitochondrial $\mathrm{F}_{0}$-ATPase. These results indicate that $\mathrm{H}_{2} \mathrm{O}_{2}$ causes a rapid and profound fall in cellular ATP levels similar to that seen when ATP production is arrested by metabolic inhibitors.
\end{abstract}

\section{Introduction}

Exposure of certain mammalian cells and organs to oxygen radicals formed by the reduction of molecular oxygen has been shown to result in cell dysfunction and death. Liberation of intracellular enzymes and release of ${ }^{51} \mathrm{Cr}$ from previously labeled cells occurs several hours after exposure of a variety of cells including cultured endothelial cells, tumor cells, and fibroblasts to oxygen radicals produced either by chemical-generating systems or by stimulated polymorphonuclear leukocytes (PMN) (1-4). In addition, lung edema and postischemic organ edema occur coincident with exposure to oxygen radicals (5-7).

Drs. Hinshaw, Hyslop, and Schraufstätter are recipients of fellowships from the American Lung Association, the American Heart Association, and the Puritan Bennett Foundation, respectively. Address communications and reprint requests to Dr. Spragg, University of California, San Diego.

Received for publication 7 December 1984 and in revised form 29 April 1985.

J. Clin. Invest.

(c) The American Society for Clinical Investigation, Inc.

$0021-9738 / 85 / 10 / 1471 / 06 \$ 1.00$

Volume 76, October 1985, 1471-1476
Although oxidation of proteins, lipids, and deoxyribonucleic acids may play a role in the cellular and organ dysfunction induced by oxidant exposure (8-10), specific cellular events resulting from oxidant injury and necessary for cell death are yet unknown. While studying the relationships between blood platelet adenosine triphosphate (ATP), adenylate energy charge, and platelet function, Holmsen and Robkin (11) found that $\mathrm{H}_{2} \mathrm{O}_{2}$ caused a rapid conversion of metabolically available ATP to inosine and/or hypoxanthine. This conversion was augmented by the presence of catalase inhibitors and was not accompanied by significant changes in inorganic phosphate concentration. Absolute changes in ATP levels in the metabolic pool were not measured. Endothelial cells have also been noted to undergo alterations in adenylate metabolism after exposure to $\mathrm{H}_{2} \mathrm{O}_{2}$ or xanthine oxidase/xanthine. Ager (12) reported increased release of ${ }^{3} \mathrm{H}$ from cells preincubated with $\left[{ }^{3} \mathrm{H}\right]$ adenosine and then exposed to oxidants. In addition, cell uptake of $\left[{ }^{3} \mathrm{H}\right]$ adenine was inhibited in a dose-dependent fashion by exposure to $>0.1$ $\mathrm{mM} \mathrm{H} \mathrm{O}_{2}$.

Because adenine nucleotides participate in many metabolic reactions and are major factors in maintaining cellular homeostasis (13), we investigated adenine nucleotide alterations in two cultured cell lines, early passage bovine aortic endothelial cells and $\mathrm{P} 388 \mathrm{D}_{1}$ murine macrophages, after exposure of those cells to $\mathrm{H}_{2} \mathrm{O}_{2}$ (delivered either as a bolus or by the enzymatic oxidation of glucose by glucose oxidase) or to stimulated PMN. Because the energy charge [(ATP + 1/2 ADP)/(ATP + ADP + AMP)] of a cell has been related to control of multiple metabolic functions, that value was determined. We have demonstrated a rapid and profound fall in cellular ATP levels and energy charge after exposure to these oxygen radicals. This fall precedes other evidence of cell injury and is consistent with a marked reduction of phosphorylation of ADP.

\section{Methods}

Chemicals. Superoxide dismutase (SOD), ${ }^{1}$ luciferin-luciferase, and oligomycin were obtained from Calbiochem, La Jolla, CA; culture media from Gibco Laboratories, Santa Clara, CA; fetal calf serum from Flow Laboratories, Inglewood, $\mathrm{CA} ;{ }^{51} \mathrm{Cr}$ from New England Nuclear, Boston, MA; the remainder of chemicals used from Sigma Chemical Co., St. Louis, MO.

Cell culture. The murine macrophagelike cell line $\mathrm{P}_{388} \mathrm{D}_{1}$ has been previously described (14). It was maintained in RPMI-1640 medium supplemented with $10 \%$ fetal calf serum, $2 \mathrm{mM}$ glutamine, and $50 \mu \mathrm{g} /$ $\mathrm{ml}$ gentamycin sulfate. Cells were grown just to confluence in $150-\mathrm{cm}^{2}$ flasks (Corning Glass Works, Corning, NY) and used immediately. When exposed to FNLP $(2.6 \mu \mathrm{M})$ or PMA $(100 \mu \mathrm{g} / \mathrm{ml})$, these cells showed no evidence of $\mathrm{O}_{2}^{-}$liberation as assessed by ability to reduce cytochrome $c$. Bovine aortic endothelial cells, a gift of Dr. David Loskutoff, Department

1. Abbreviations used in this paper: HPLC, high performance liquid chromatography; MEM, minimal essential medium; PMA, phorbol myristate acetate; SOD, superoxide dismutase. 
of Immunology, the Research Institute of Scripps Clinic, were grown to confluence on Cytodex 3 microcarrier beads (Pharmacia Fine Chemicals, Uppsala, Sweden) $(25 \mathrm{mg} / \mathrm{ml})$ in spinner culture flasks (Techne Instruments Co., Princeton, NJ) in minimal essential medium (MEM) supplemented with $10 \%$ calf serum, $5 \mathrm{mM}$ glutamine, $100 \mathrm{U} / \mathrm{ml}$ penicillin $\mathrm{G}$, and $100 \mu \mathrm{g} / \mathrm{ml}$ streptomycin (15). Both cell cultures were maintained in $5 \% \mathrm{CO}_{2}$ in air at $37^{\circ} \mathrm{C}$.

Cell suspension for experiments. $\mathrm{P}_{388 \mathrm{D}_{1}}$ cells were suspended using a rubber policeman, centrifuged at $500 \mathrm{~g}$ for $5 \mathrm{~min}$ and resuspended at a concentration of $2 \times 10^{6} / \mathrm{ml}$ in RPMI- 1640 with $20 \mathrm{mM}$ Hepes at $37^{\circ} \mathrm{C}$ unless otherwise noted. Cell counts were performed with a hemocytometer or counter (Coulter Electronics Inc., Hialeah, FL). Cell viability as assayed by Trypan Blue exclusion was always $>95 \%$ in all initial cell suspensions. $10 \mu \mathrm{l}$ of $0.1 \%$ Trypan Blue in $0.9 \% \mathrm{NaCl}$ was added to $90 \mu \mathrm{l}$ of a suspension of $2 \times 10^{6} \mathrm{cells} / \mathrm{ml}$ and the cells were examined in a hemocytometer under light microscopy. For studies of ${ }^{51} \mathrm{Cr}$ release, $2 \times 10^{6}$ cells $/ \mathrm{ml}$ were labeled with $1 \mu \mathrm{Ci}{ }^{51} \mathrm{Cr} / \mathrm{ml}$ for 30 min, washed once, and resuspended. ${ }^{51} \mathrm{Cr}$-release was assayed by gamma scintillation spectrometry of $1 \mathrm{ml}$ of cell supernatant after pelleting of the cells. Endothelial cells on microcarrier beads were pipetted from the culture flask, allowed to settle, and resuspended in MEM 199 with 20 $\mathrm{mM}$ Hepes. Cell number was indexed by the amount of DNA present per milliliter sample using a fluorimetric assay (16).

ATP by luciferin/luciferase. $100 \mu \mathrm{l}$ of cell suspension was added to $2.0 \mathrm{ml} 10 \mathrm{mM} \mathrm{KH}_{2} \mathrm{PO}_{4}, 4 \mathrm{mM} \mathrm{MgSO}{ }_{4}, \mathrm{pH} 7.4$, at $95^{\circ}-99^{\circ} \mathrm{C}$. After 4 min, samples were placed in ice and assayed within $4 \mathrm{~h}$. At the time of assay, $1 \mathrm{ml}$ sample was added to $2 \mathrm{ml} 50 \mathrm{mM} \mathrm{NaAsO}$, and $20 \mathrm{mM}$ $\mathrm{MgSO}_{4}, \mathrm{pH} 7.40 .50 \mu$ luciferin/luciferase was added, and precisely 15 $s$ later the light emission was quantified in a LS 8000 beta counter (Beckman Instruments, Inc., Fullerton, CA) with the photomultiplier tube signals accepted out of coincidence (17). Pulse height analyzer channels 81-120 were recorded, as preliminary calibration showed $80 \%$ of the photon peak to be in this region. Standards were prepared in $100 \mathrm{mM}$ $\mathrm{KH}_{2} \mathrm{PO}_{4}, 4 \mathrm{mM} \mathrm{MgSO}$ buffer, and ATP concentration was measured spectrophotometrically at $259 \mathrm{~nm}$ using an extinction coefficient of 15,400 . Standard curves of $\log$ photon counts vs. $\log$ [ATP] were linear from $10^{-9}$ to $10^{-5} \mathrm{M}$ ATP.

Rate of de novo purine synthesis. $\mathrm{P}_{388} \mathrm{D}_{1}$ cells in suspension were exposed to various concentrations of $\mathrm{H}_{2} \mathrm{O}_{2}$ and $\left[{ }^{14} \mathrm{C}\right]$ formate $(250 \mu \mathrm{M}$, $40 \mathrm{mCi} / \mathrm{mM}$ ) was added either immediately or after $30 \mathrm{~min}$. Cells were incubated for $1 / 2 \mathrm{~h}$ after the addition of formate, centrifuged, and the cell pellets and supernatants were separately extracted with $1 \mathrm{ml} 0.4 \mathrm{~N} \mathrm{HClO}_{4}$. The extracts were hydrolyzed for $70 \mathrm{~min}$ at $100^{\circ} \mathrm{C}$, chilled to $0^{\circ} \mathrm{C}$, centrifuged, and free purine bases (derived from intracellular purine-containing nucleotides and polynucleotides) or purine bases released to the media were isolated using the methods of Hershfield and Seegmiller (18) and counted to determine the rate of labeling of total intracellular purines. Because the media was free of hypoxanthine, guanine, or adenine, the comparative net rates of purine synthesis before and after oxidant injury were estimated.

High pressure liquid chromatography (HPLC). Experiments for HPLC analysis were performed with $\mathrm{P}_{388 \mathrm{D}_{1}}$ cells at a density of $2 \times 10^{7}$ cells $/ \mathrm{ml} ; 1.5-\mathrm{ml}$ samples of cell suspension were taken into Eppendorf tubes, centrifuged in a microfuge for $30 \mathrm{~s}$, and the supernatant was removed and saved for analysis. The pellet was extracted with 0.5 $\mathrm{ml}$ of iced $0.8 \mathrm{~N} \mathrm{HClO}_{4}$, and after removing acid-insoluble material by centrifugation, the supernatants were neutralized by treatment with Alamine 336 (General Mills, Inc., Minneapolis, MN) in freon-TF $(1,1,2-$ trichlorotrifluoroethane, Aldrich Chemical Co., Milwaukee, WI) (19). Nucleotides in the original cell pellet supernatant and the cell pellet extract were separated on an Ultrasil AX anion exchange column (Altex Scientific, Inc., Berkeley, CA) according to the method of Pogliotti (20). Nucleosides and bases were separated on a C18 reverse-phase column (DuPont Co., Willington, DE) using a gradient of buffer A (10 mM $\left.\mathrm{K}_{2} \mathrm{HPO}_{4}, \mathrm{pH} 3.3\right)$ and solvent $\mathrm{B}\left(60 \%\right.$ acetonitrile in $10 \mathrm{mM} \mathrm{K}_{2} \mathrm{HPO}_{4}$, $\mathrm{pH} 4.0$ ) at a flow rate of $1.5 \mathrm{ml}$. After equilibration at $99 \% \mathrm{~A}, 1 \% \mathrm{~B}$, an $11 \%$ gradient to $88 \%$ A, $12 \%$ B was run over $25 \mathrm{~min}$. A Series 4 liquid chromatograph with an LC-75 variable detector set at $256 \mathrm{~nm}$ was used
(Perkin Elmer Corp., Norwalk, CT). Solutions of nucleotide, nucleoside, and base standards whose concentrations had been established by ultraviolet absorbance were used to establish retention times and convert peak areas to nanomoles.

Exposure of $P 388 D_{1}$ cells to metabolic inhibitors. Cells were washed 1 time, suspended in low $\mathrm{K}^{+}$buffer $(0.65 \mathrm{mM} \mathrm{KCl}, 145 \mathrm{mM} \mathrm{NaCl}, 1$ $\mathrm{mM} \mathrm{CaCl}$, and $10 \mathrm{mM}$ Hepes, $\mathrm{pH} 7.4)$ at $2 \times 10^{6} / \mathrm{ml}$, incubated for $20 \mathrm{~min}$ at $24^{\circ} \mathrm{C}$ in the presence or absence of $0.1 \mathrm{mM}$ ouabain, and then exposed to $5 \mathrm{mM} \mathrm{H}_{2} \mathrm{O}_{2}$ or phosphate-buffered saline (PBS). Samples were taken frequently over the subsequent $30 \mathrm{~min}$.

Cells in RPMI/Hepes $(20 \mathrm{mM})$ at a concentration of $2 \times 10^{6} / \mathrm{ml}$ were exposed to $\pm 25 \mu \mathrm{g}$ oligomycin $/ \mathrm{ml}$ (equivalent to $111 \mu \mathrm{g} / \mathrm{mg}$ cell protein) for $3 \mathrm{~min}$ and then to $\pm 5 \mathrm{mM} \mathrm{H}_{2} \mathrm{O}_{2}$. Samples were taken frequently over the subsequent $30 \mathrm{~min}$. In additional experiments, cells were exposed to \pm oligomycin at the concentrations stated, and to \pm 2 deoxyglucose (10 mM) for $3 \mathrm{~min}$, and then to $\pm \mathrm{H}_{2} \mathrm{O}_{2}(5 \mathrm{mM})$.

Measurement of $\mathrm{H}_{2} \mathrm{O}_{2}$ levels. $\mathrm{H}_{2} \mathrm{O}_{2}$ in the extracellular medium was assayed using the fluorometric assay described by Hyslop and Sklar (21). Cell suspensions were rapidly centrifuged and $0.15 \mathrm{ml}$ of the supernatant was taken for $\mathrm{H}_{2} \mathrm{O}_{2}$ determination.

\section{Results}

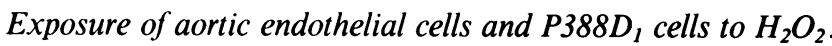
When endothelial cells were exposed to 1,5 , or $8.3 \mathrm{mM} \mathrm{H}_{2} \mathrm{O}_{2}$, a rapid and substantial loss of intracellular ATP was observed (Fig. 1). This loss persisted for $3 \mathrm{~h}$ without evidence of recovery.

When $P 388 D_{1}$ were exposed to $\mathrm{H}_{2} \mathrm{O}_{2}$, a rapid and profound decrement in ATP levels was always demonstrable, as shown in Fig. 2. This result was not due to a simple effect of $\mathrm{H}_{2} \mathrm{O}_{2}$ on ATP, since exposure of $5 \mu \mathrm{M}$ ATP to $0.005,0.05,0.5$, or $5 \mathrm{mM}$ $\mathrm{H}_{2} \mathrm{O}_{2}$ for 10 min resulted in recovery of $99 \pm 4 \%$. Neither was loss of measurable ATP due to loss of cells from the cell suspension, for cell counts of suspensions were unchanged after $\mathrm{H}_{2} \mathrm{O}_{2}$ exposure. In addition, ATP was not detected in the extracellular media.

The early loss of P388D ATP was in contrast to release of ${ }^{51} \mathrm{Cr}$ from labeled cells into the medium. Cells exposed to $5 \mathrm{mM}$ $\mathrm{H}_{2} \mathrm{O}_{2}$ released intracellular ${ }^{51} \mathrm{Cr}$ at a rate of $6.5 \% / \mathrm{h}$ over $4 \mathrm{~h}$ of incubation $(r=0.99, n=3)$, whereas control cells did not exhibit progressive loss of ${ }^{51} \mathrm{Cr}$. In addition, cells exposed to $5 \mathrm{mM} \mathrm{H}_{2} \mathrm{O}_{2}$ showed $>95 \%$ Trypan Blue exclusion for the first hour after exposure. This value then gradually declined to $50 \%$ at $3 \mathrm{~h}$ (data not shown)

The effect of various doses of $\mathrm{H}_{2} \mathrm{O}_{2}$ on $\mathrm{P} 388 \mathrm{D}_{1}$ ATP levels, shown in Fig. 3, demonstrates dose dependency, both of the extent of the ATP decrement and of the rate of ATP restoration. Exposure to $5 \mathrm{mM} \mathrm{H}_{2} \mathrm{O}_{2}$ resulted in fall of ATP to $<98 \%$ control levels, with no recovery over $4 \mathrm{~h}$. This fall begins $45 \mathrm{~s}$ after the addition of $\mathrm{H}_{2} \mathrm{O}_{2}$ (data not shown). The concentration of $\mathrm{H}_{2} \mathrm{O}_{2}$ in the extracellular medium was measured, and fell exponentially from the initial value, with $t_{1 / 2}=14.4,11.3,8.7$, or $7.7 \mathrm{~min}$ with

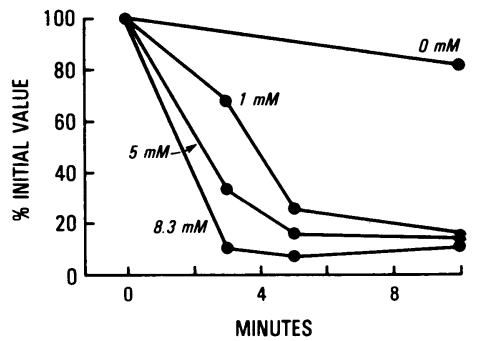

Figure 1. Bovine aorta endothelial cell ATP levels after $\mathrm{H}_{2} \mathrm{O}_{2}$ exposure. Bovine aortic endothelial cells on Cytodex beads were exposed to different concentrations of $\mathrm{H}_{2} \mathrm{O}_{2}$ at $t=0$, and samples were withdrawn for ATP determinations at various times. Results are expressed as percentage of control value of $100 \%=2.6 \pm 0.6$ $\times 10^{-9} \mathrm{~mol} \mathrm{ATP} / \mu \mathrm{g}$ DNA (mean of three experiments). 


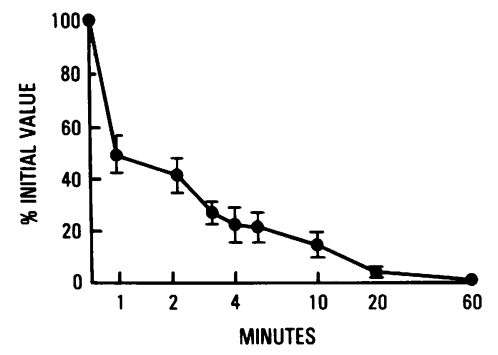

Figure 2. $\mathrm{P} 388 \mathrm{D}_{1}$ ATP levels after exposure to $5 \mathrm{~mm}$ $\mathrm{H}_{2} \mathrm{O}_{2}$. $\mathrm{P} 388 \mathrm{D}_{1}$ cells were exposed to $5 \mathrm{mM} \mathrm{H}_{2} \mathrm{O}_{2}$ at $t=0$, and samples were withdrawn for ATP (luciferin/luciferase) determinations at various times.

Graph is a composit of all such experiments per-

formed. Results are expressed as percentage of control (exposed to saline) \pm SEM; control values vary by $<11 \%$ over $240 \mathrm{~min} ; 100 \%$ $=4.9 \pm 0.2(\mathrm{SEM}) \mathrm{nmol} \mathrm{ATP} / 10^{6}$ cells $(n=16)$. Values for $t=120$, $180,240 \mathrm{~min}=<1 \%$.

initial $\mathrm{H}_{2} \mathrm{O}_{2}$ concentrations of $5,2.5,1.0$, or $0.5 \mathrm{mM}$, respectively. In the absence of cells, $\mathrm{H}_{2} \mathrm{O}_{2} t_{1 / 2}$ was $>8 \mathrm{~h}$.

The effect of intracellular catalase on attenuating the fall in ATP was demonstrated by preincubating $\mathrm{P}_{388 \mathrm{D}_{1} \text { for } 20 \mathrm{~min}}$ with $1 \mathrm{mg} / \mathrm{ml} \mathrm{3-amino} \mathrm{1,2,4} \mathrm{triazole} \mathrm{(aminotriazole).} \mathrm{Cells} \mathrm{ex-}$ posed to aminotriazole lose catalase activity in the presence of $\mathrm{H}_{2} \mathrm{O}_{2}$. These cells were then exposed to a range of $\mathrm{H}_{2} \mathrm{O}_{2}$ concentrations (Fig. 4). Cells so treated demonstrated increased $\mathrm{H}_{2} \mathrm{O}_{2}$-dependent loss of ATP when compared with cells not exposed to aminotriazole. In separate experiments, rates of azidesensitive disappearance of $\mathrm{H}_{2} \mathrm{O}_{2}$ were determined in $\mathrm{P} 388 \mathrm{D}_{1}$ cell suspensions. Since azide effectively abolishes catalase activity, these rates are a direct measure of catalase activity and document the effect of aminotriazole pretreatment. Cells, either preexposed for $20 \mathrm{~min}$ to $1 \mathrm{mg} / \mathrm{ml}$ aminotriazole or not, were exposed in the presence or absence of $167 \mu \mathrm{M}$ sodium azide to $1.0 \mathrm{mM}$ $\mathrm{H}_{2} \mathrm{O}_{2}$, and the disappearance of $\mathrm{H}_{2} \mathrm{O}_{2}$ was monitored. Azidesensitive $t_{1 / 2}$ for the disappearance of $\mathrm{H}_{2} \mathrm{O}_{2}$ was 7.9 and 37.0 min in the absence or presence of aminotriazole, respectively. Thus, aminotriazole preexposure significantly reduced $\mathrm{P}_{388} \mathrm{D}_{1}$ catalase activity.

To investigate the time of exposure to $\mathrm{H}_{2} \mathrm{O}_{2}$ required for the

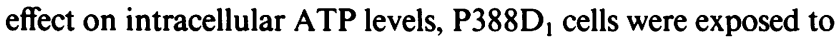
$1 \mathrm{mM} \mathrm{H}_{2} \mathrm{O}_{2}$ for variable lengths of time, after which catalase was added to inactivate the remaining $\mathrm{H}_{2} \mathrm{O}_{2}$ (Fig. 5). Cellular ATP levels were measured after $10 \mathrm{~min}$. As shown in Fig. 5 ,

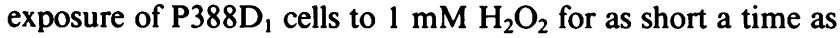
$30 \mathrm{~s}$ induced a marked decrement in ATP levels. When cells were exposed for 300 or 600 s, ATP levels were 57 and $34 \%$ of control, respectively.

Exposure of $P 388 D_{1}$ to other oxidant-generating systems. When exposed to xanthine oxidase $(31 \mathrm{mU})$ plus acetaldehyde $(33 \mathrm{mM})$, or to glucose oxidase $(48 \mathrm{mU})$ in the presence of 5 $\mathrm{mM}$ glucose, $\mathrm{P}_{388 \mathrm{D}_{1}}$ ATP levels fell to $<5 \%$ within $1 \mathrm{~h}$ and

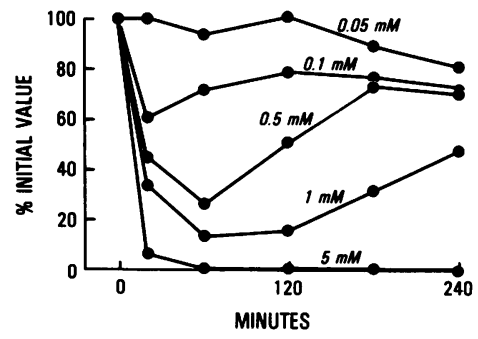

Figure 3. $\mathrm{P} 388 \mathrm{D}_{1}$ ATP levels after $\mathrm{H}_{2} \mathrm{O}_{2}$ exposure. P388D 1 cells were exposed to levels of $\mathrm{H}_{2} \mathrm{O}_{2}$ as indicated, and ATP (luciferin/ luciferase) determinations were performed on samples obtained over $4 \mathrm{~h}$. Results are expressed as percentage of initial values, which averaged $4.8 \pm 0.1$ (SEM) $\mathrm{nmol}$ ATP $/ 10^{6}$ cells (mean of three experiments).

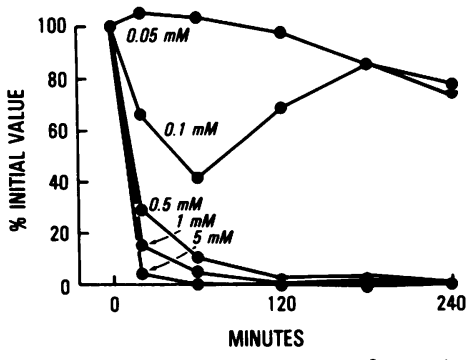

Figure 4. $\mathrm{P} 388 \mathrm{D}_{1}$ ATP levels after aminotriazole and $\mathrm{H}_{2} \mathrm{O}_{2}$. $\mathrm{P} 388 \mathrm{D}$, cells from the harvest used for the experiment in Fig. 3 were preincubated for $20 \mathrm{~min}$ at $37^{\circ} \mathrm{C}$ with $1 \mathrm{mg} / \mathrm{ml}$ aminotriazole and then exposed to the levels of $\mathrm{H}_{2} \mathrm{O}_{2}$ indicated. ATP (luciferin/luciferase) determinations were performed on samples obtained over $4 \mathrm{~h}$. Results are expressed as percentage of initial values, which averaged $4.6 \pm 0.2(\mathrm{SEM}) \mathrm{nmol} \mathrm{ATP} / 10^{6}$ cells (mean of three experiments).

remained at that level for $4 \mathrm{~h}$. Identical concentrations of glucose oxidase plus glucose in the absence of cells generated $\mathrm{H}_{2} \mathrm{O}_{2}$ at an initial rate of $0.8 \mu \mathrm{M} / \mathrm{min}$. ATP levels of controls exposed to buffer, acetaldehyde, or glucose were $>85 \%$ control after $4 \mathrm{~h}$.

To determine if PMN stimulated by phorbol myristate acetate (PMA) could cause a decrement in P388D $\mathrm{D}_{1}$ ATP levels, $\mathrm{P}_{388 \mathrm{D}_{1}}$ and PMN were incubated for 30 min either separately or together and in either the presence of or absence of PMA. In

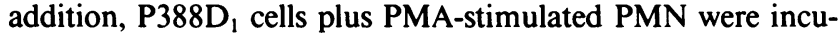
bated in the presence of SOD plus catalase. Results, shown in Fig. 6, demonstrate SOD plus catalase inhibitable decrement of P388D 1 ATP only in the presence of PMA-stimulated PMN.

Effect of ouabain or oligomycin on ATP level after $\mathrm{H}_{2} \mathrm{O}_{2}$ exposure. Because the stimulation of the membrane $\mathrm{Na}^{+}-\mathrm{K}^{+}-$ ATPase by augmented passive ion flux after oxidative membrane damage might contribute to the observed decrement in intracellular ATP, experiments were performed in which ouabain was used to inhibit that ATPase (22). Similarly, injury to the inner mitochondrial membrane might result in loss of the transmembrane proton gradient and hydrolysis of ATP by the oligomycin-sensitive ATPase (23). Therefore, experiments were performed in which oligomycin was used to block that ATPase. In neither case was protection from the $\mathrm{H}_{2} \mathrm{O}_{2}$-induced decrement in ATP seen (data not shown).

Effect of oligomycin and 2-deoxyglucose on P388D ATP levels. To investigate whether complete interruption of phosphorylation of ADP might result in a fall in P388D 1 ATP levels at a rate similar to that seen after oxidant injury, cells were exposed to oligomycin (to inhibit mitochondrial oxidative phosphorylation) and 2-deoxyglucose (to inhibit glycolysis). As seen in Fig. 7, exposure to oligomycin resulted in a $29 \%$ fall in ATP after $13 \mathrm{~min}$, exposure to 2-deoxyglucose resulted in a $77 \%$ fall in ATP after $13 \mathrm{~min}$, and exposure to oligomycin plus 2-deoxyglucose resulted in a $97 \%$ fall in ATP after 13 min. When cells

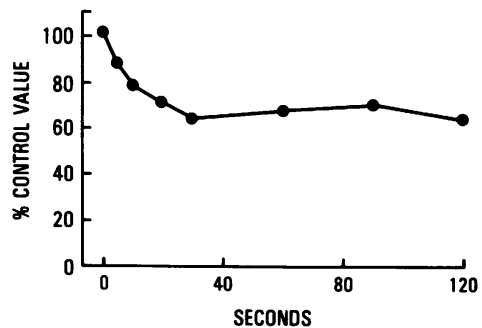

Figure 5. Influence of time of exposure to $\mathrm{H}_{2} \mathrm{O}_{2}$ on P388D ATP level 10 min after onset of exposure. P388 $_{1}$ cells were exposed to $1 \mathrm{mM} \mathrm{H}_{2} \mathrm{O}_{2}$, and after the time interval indicated on the abcissa, catalase $(100,000 \mathrm{U} / \mathrm{ml})$ was added. ATP (luciferin/luciferase)

levels were determined 10 min after initial exposure to $\mathrm{H}_{2} \mathrm{O}_{2}$. Results are expressed as percentage of initial value, which was $3.4 \mathrm{nmol}$ ATP/ $10^{6}$ cells. $\mathrm{H}_{2} \mathrm{O}_{2}$ was undetectable in cell supernatants immediately after catalase addition (mean of three experiments). 


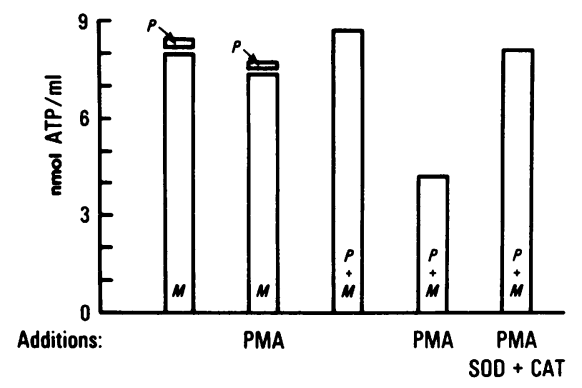

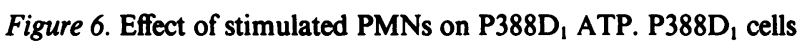
(M) $\left(2 \times 10^{6} / \mathrm{ml}\right)$ and PMN (P) $\left(1 \times 10^{6} / \mathrm{ml}\right)$ were incubated either separately (broken bars) or together in either the absence or presence of PMA $(2.5 \mu \mathrm{l} / \mathrm{ml})$. ATP determinations (luciferin/luciferase) were made at $30 \mathrm{~min}$. $\mathrm{SOD}=1,000 \mathrm{U} / \mathrm{ml}$; catalase $=5,000 \mathrm{U} / \mathrm{ml}$ (mean of three experiments).

preexposed to 2-deoxyglucose and oligomycin for $3 \mathrm{~min}$ were exposed to $5 \mathrm{mM} \mathrm{H}_{2} \mathrm{O}_{2}$, the level of ATP fell by $95 \%$ over the 13-min total exposure.

ATP breakdown products and alterations in energy charge. $\mathrm{P} 388 \mathrm{D}_{1}$ cells were exposed to $\mathrm{H}_{2} \mathrm{O}_{2}$ at a ratio of $2 \times 10^{6}$ cells/ $5 \mathrm{mM} \mathrm{H}_{2} \mathrm{O}_{2}$. Table I shows the result of analysis of cell pellet extracts and cell supernatants for nucleotides, nucleosides, and bases. The decrement in ATP was largely accounted for by the increase in inosine monophosphate (IMP) and inosine; release of other cell constituents obscured further interpretation of chromatograms of supernatant fluids for nucleosides and bases. Nucleotides were found only in the cell pellet extract. ADP values increased slightly, while AMP values increased ninefold after $\mathrm{H}_{2} \mathrm{O}_{2}$ exposure. The energy charge (13) [(ATP $+1 / 2$ ADP)/(ATP + ADP + AMP)] fell from 0.95 to values of 0.66 and less within $1 \mathrm{~min}$.

HPLC analyses of extracts of cells that had been exposed for $6 \mathrm{~min}$ to oligomycin plus 2-deoxyglucose were performed to see if nucleotide alterations were qualitatively similar to those seen after $\mathrm{H}_{2} \mathrm{O}_{2}$ exposure. As seen in Table II, ADP levels did not change, while AMP levels increased 3.2-fold, IMP levels increased fivefold, and inosine levels increased 18-fold. Values in control cells were different from those shown in Table I because of the necessary absence of a nutrient medium.

De novo purine synthesis. To investigate the relationship between the rapid fall in purine nucleotides and the rate of purine synthesis, cells were exposed to $\mathrm{H}_{2} \mathrm{O}_{2}$ and the incorporation of $\left[{ }^{14} \mathrm{C}\right]$ formate into purine bases was determined. Incorporation measured from 0 to 30 or 30 to $60 \mathrm{~min}$ after exposure to $\mathrm{H}_{2} \mathrm{O}_{2}$

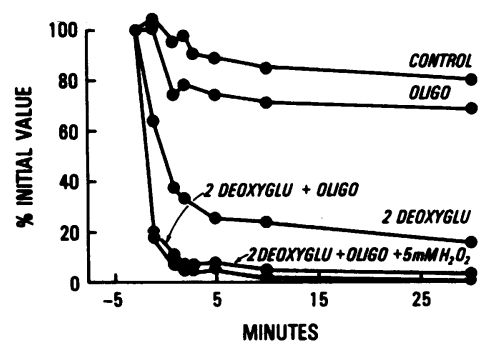

Figure 7. ATP levels after oligomycin and 2-deoxyglucose. $P 388 D_{1}$ cells suspended in Gey's buffer were exposed to oligomycin (oligo) (25 $\mu \mathrm{g}$ in $3 \mu \mathrm{l} \mathrm{EtOH/}$ ml cell suspension, equivalent to $111 \mu \mathrm{g}$ oligomycin/ mg cell protein), 2-deoxyglucose ( 2 deoxyglu) $(10$

$\mathrm{mM})$, both (2-deoxyglu + oligo), or $3 \mu \mathrm{l} \mathrm{EtOH} / \mathrm{ml}$ (control) at $t=-3$ $\min$. At $t=0$, an aliquot exposed to oligomycin +2 deoxyglucose was further exposed to $5 \mathrm{mM} \mathrm{H}_{2} \mathrm{O}_{2}$. ATP (luciferin/luciferase) was determined at the times indicated (mean of three experiments).
Table I. Purine Nucleotides and Inosine* After Exposure to $\mathrm{H}_{2} \mathrm{O}_{2}$ or Buffer $\neq$

\begin{tabular}{llllll}
\hline & $\mathrm{H}_{2} \mathrm{O}_{2}$ & & & & \multicolumn{1}{c}{ Buffer } \\
\cline { 2 - 5 }$t=(\min )$ & 0 & 1 & 3 & 6 & 6 \\
\hline ATP & 3.19 & 0.54 & 0.26 & 0.15 & 3.37 \\
ADP & 0.28 & 0.40 & 0.30 & 0.21 & 0.31 \\
AMP & 0.02 & 0.18 & 0.21 & 0.16 & 0.02 \\
IMP & 0.03 & 2.06 & 2.28 & 1.80 & 0.05 \\
GTP & 0.41 & 0.14 & 0.09 & 0.06 & 0.43 \\
GDP & 0.03 & 0.14 & 0.13 & 0.09 & 0.04 \\
GMP & 0.01 & 0.07 & 0.10 & 0.08 & 0.01 \\
Inosine & 0 & 0.85 & 0.72 & 0.56 & 0 \\
Sum & 3.97 & 4.38 & 4.09 & 3.11 & 4.23 \\
Energy charge & 0.95 & 0.66 & 0.53 & 0.65 & 0.95 \\
\hline
\end{tabular}

* Nanomoles per $10^{6} \mathrm{P} 388 \mathrm{D}_{1}$ cells.

$¥$ Cells were suspended in RPMI media and exposed to $\mathrm{H}_{2} \mathrm{O}_{2}(5 \mu \mathrm{mol}$ : $2 \times 10^{6}$ cells) or buffer for the times shown, rapidly pelleted, and extracted with $0.4 \mathrm{~N} \mathrm{HClO}_{4}$. The extract was neutrolized with alamine/ freon and analyzed by HPLC (mean of two experiments). GDP, guanosine diphosphate; GMP, guanosine 3'5'-monophosphate; GTP, guanosine triphosphate.

was similar, and was 39,15 , and $4 \%$ of control when cells were exposed to 50,100 , and $500 \mu \mathrm{M} \mathrm{H} \mathrm{H}_{2} \mathrm{O}_{2}$, respectively ( $n=3$; control cells incorporated $26,640 \mathrm{dpm} / 10^{6}$ cells per $30 \mathrm{~min}$ ).

\section{Discussion}

Experiments reported here demonstrate that intracellular ATP levels fall markedly when either of the cell lines studied is exposed to $\mathrm{H}_{2} \mathrm{O}_{2}$. Detailed study of $\mathrm{P} 388 \mathrm{D}_{1}$ cells shows that this response

Table II. Purine Nucleotides and Inosine* 6 min After Exposureł

\begin{tabular}{lll}
\hline & $\begin{array}{l}\text { Oligomycin }\left(1.25 \mu \mathrm{g} / 10^{6} \text { cells }\right) \\
\text { plus } \\
\text { 2-deoxyglucose }(10 \mathrm{mM})\end{array}$ & Control \\
\hline ATP & 0.37 & 2.67 \\
ADP & 0.52 & 0.51 \\
AMP & 1.31 & 0.41 \\
IMP & 1.00 & 0.19 \\
GTP & 0.14 & 0.62 \\
GDP & 0.27 & 0.15 \\
GMP & 0.33 & 0.02 \\
Inosine & 0.18 & 0.01 \\
Sum & 4.12 & 4.58 \\
Energy charge & 0.19 & 0.81
\end{tabular}

* Nanomoles per $10^{6} \mathrm{P} 388 \mathrm{D}_{1}$ cells.

¥ Cells were suspended in Gey’s buffer and exposed to oligomycin and 2-deoxyglucose or buffer for $6 \mathrm{~min}$, rapidly pelleted, and extracted with $0.4 \mathrm{~N} \mathrm{HClO}_{4}$. The extract was neutrolized with alamine/freon and analyzed by HPLC (mean of three experiments). GDP, guanosine diphosphate; GMP, guanosine 3'5'-monophosphate; GTP, guanosine triphosphate. 
occurred after exposure to a variety of oxidant sources which included bolus $\mathrm{H}_{2} \mathrm{O}_{2}$ and enzymatically generated $\mathrm{H}_{2} \mathrm{O}_{2}$ and $\mathrm{O}_{\dot{2}}^{\dot{2}}$.

Neutrophils stimulated by PMA were similarly able to cause a reduction in $\mathrm{P} 388 \mathrm{D}_{1} \mathrm{ATP}$, and this effect was fully inhibitable by catalase plus SOD. The neutrophil-induced ATP fall of $\sim 45 \%$ over $30 \mathrm{~min}$ corresponds to the effect of an initial exposure to $0.1 \mathrm{mM} \mathrm{H} \mathrm{O}_{2}$ for $30 \mathrm{~min}$ (Fig. 2). As the $t_{1 / 2}$ for $\mathrm{H}_{2} \mathrm{O}_{2}$ under these conditions was $7 \mathrm{~min}$, the 30 -min exposure is equivalent to a total exposure of $\sim 1.0 \mathrm{mM} / \mathrm{min}$ (the integral value of the $\mathrm{H}_{2} \mathrm{O}_{2}$ concentration with respect to time). Test and Weiss (24) report the production of $0.6 \mathrm{mM} / \mathrm{min} \mathrm{H}_{2} \mathrm{O}_{2}$ from $3 \times 10^{5}$ neutrophils/ml in the presence of PMA, and approximately a twofold increase in $\mathrm{H}_{2} \mathrm{O}_{2}$ concentration occurring with a fourfold increase in cell concentration. Thus, the fall in ATP seen in target $\mathrm{P}_{388 \mathrm{D}_{1}}$ exposed to PMA-stimulated PMN is consistent with the $\mathrm{H}_{2} \mathrm{O}_{2}$ sensitivity of $\mathrm{P} 388 \mathrm{D}_{1}$ demonstrated in this report and the known capabilities of PMN to produce $\mathrm{H}_{2} \mathrm{O}_{2}$.

The impact of $\mathrm{H}_{2} \mathrm{O}_{2}$ on cellular ATP was augmented by aminotriazole-induced reduction in intracellular catalase. This reduction occurs because of the high affinity complex formed between aminotriazole and compound I (catalase plus $\mathrm{H}_{2} \mathrm{O}_{2}$ ), effectively removing functional catalase from the cell (25). The more pronounced fall in ATP seen in aminotriazole-exposed cells is consistent with the observations of Holmsen and Robkin (11) that catalase inhibitors augmented the loss of intracellular ATP.

Decreased phosphorylation of ADP-both from glycolysis and from mitochondrial oxidative phosphorylation-might result in a fall in the concentration of ATP and energy charge, with a consequent increased metabolism of ADP to AMP to IMP (via adenylate deaminase) (26). Although the control mechanisms for these metabolic steps have not been determined in $\mathrm{P} 388 \mathrm{D}_{1}$, the data from cells exposed to $\mathrm{H}_{2} \mathrm{O}_{2}$ demonstrate that accumulation of AMP and IMP accounts (during the initial $6 \mathrm{~min}$ ) for the amount of ATP lost.

Qualitatively similar results were obtained when phosphorylation of ADP was arrested by exposing cells to oligomycin and 2-deoxyglucose. Oligomycin exposure caused a modest fall in cell ATP content; 2-deoxyglucose caused a much greater fall (Fig. 7). The predominance of glycolytic production of ATP has been described in other cultured cell lines (27). Arrest of both glycolytic and mitochondrial ATP production caused a rapid fall in ATP over a time course roughly equivalent to that seen after exposure of cells to $5 \mathrm{mM} \mathrm{H}_{2} \mathrm{O}_{2}$ (Figs. 3 and 7). In addition, this fall in ATP was accompanied by little change in ADP, and significant increases in AMP, IMP, and inosine. Thus, arrest of phosphorylation of ADP as an explanation for our experimental results is consistent with our data.

Detailed studies of glycolysis and oxidative phosphorylation in $\mathrm{P} 388 \mathrm{D}_{1}$ cells after $\mathrm{H}_{2} \mathrm{O}_{2}$ exposure will be reported separately. They disclose that lactate production falls from 1.7 to $0.6 \mathrm{nmol} /$ $10^{6}$ cells per min during 20 -min exposure to $100 \mu \mathrm{M} \mathrm{H}_{2} \mathrm{O}_{2}$, and is essentially unmeasurable during $20-\mathrm{min}$ exposure to $5 \mathrm{mM}$ $\mathrm{H}_{2} \mathrm{O}_{2}$. Glucose uptake shows similar changes. When [6${ }^{14} \mathrm{C}$ ]glucose is used to measure tricarboxylic acid cycle activity, production of ${ }^{14} \mathrm{CO}_{2}$ increases slightly (from 6 to $12 \mathrm{pmol} / 10^{6}$ cells per min). Calculated net ATP production (assuming $2 \mathrm{~mol}$ ATP $/$ mole lactate produced and $34 \mathrm{~mol} \mathrm{ATP} / \mathrm{mol}^{14} \mathrm{CO}_{2}$ produced) shows that the rate of ATP production falls by $\sim 50 \%$ over 20 min of exposure to $100 \mu \mathrm{M} \mathrm{H}_{2} \mathrm{O}_{2}$. These results assume complete coupling of oxidative phosphorylation. To the extent that uncoupling occurs, however, oxidative phosphorylation of ADP and hence net ATP production will be less.

Decreased synthesis of purine nucleotides might provide a second explanation for the fall in purine nucleotides which we observed. We believe this explanation is unlikely for two reasons. First, if arrest of purine synthesis were primarily responsible for the loss in adenylates, the total of intracellular purine nucleotides plus inosine ought to decrease dramatically. As shown in Table I, that sum is relatively constant. Secondly, data from the $\left[{ }^{14} \mathrm{C}\right]$ formate labeling experiments also support this argument. As adenine, guanine, and hypoxanthine are lacking in the cell suspension media, the de novo pathway provides the only route for net purine synthesis (18). We observed net purine synthesis to be $85-96 \%$ inhibited after exposure of $\mathrm{P}_{388 \mathrm{D}_{1}}$ to 100 and $500 \mu \mathrm{M} \mathrm{H}_{2} \mathrm{O}_{2}$. These concentrations of $\mathrm{H}_{2} \mathrm{O}_{2}$ cause far less than complete loss of ultracellular ATP (Fig. 3). Thus, additional factors must be responsible for the ATP loss observed.

A third explanation for the observed fall in intracellular ATP might be relief of the normal phosphate inhibition of AMP deaminase with loss of adenylate compounds via inappropriately increased activity of that enzyme (28). Intracellular phosphate levels might fall secondary to the increased activity of the hexose monophosphate shunt seen after $\mathrm{H}_{2} \mathrm{O}_{2}$ exposure (29). In addition, there may be increased loss of phosphate across a damaged cell membrane. Increased AMP deaminase activity appears unlikely to be a primary cause of the oxidant-induced fall in ATP, however, for if it were, we would expect to see decreased levels of AMP at the earliest times after $\mathrm{H}_{2} \mathrm{O}_{2}$ exposure. The marked increase in AMP makes this mechanism unlikely. Metabolism of AMP to IMP presumably does occur as a secondary event, however, for we found an increase in IMP coincident with loss of ATP. Either the decrease in energy charge (26) or the decrease in $\mathrm{Pi}$ (28) may be responsible for the increase in adenine nucleotide catabolism.

A final explanation for the decrease in ATP observed after $\mathrm{H}_{2} \mathrm{O}_{2}$ exposure could be increased activity of the membraneassociated cation ATPase pumps, for modest damage to lipid components of the cell membrane might allow augmented passive leak of $\mathrm{Na}^{+}, \mathrm{K}^{+}$, or $\mathrm{Ca}^{++}$across the membrane, stimulating ATPase activity. We reasoned that, if increased $\mathrm{Na}^{+}-\mathrm{K}^{+}-\mathrm{ATPase}$ pump activity contributed significantly to ATP decrement, blockage of the $\mathrm{Na}^{+}-\mathrm{K}^{+}$-ATPase with ouabain should reduce the fall in ATP seen after $\mathrm{H}_{2} \mathrm{O}_{2}$ exposure. No differences, however, were seen, and we therefore conclude a partial oxidant-induced stimulation of ATP-dependent $\mathrm{Na}^{+}-\mathrm{K}^{+}$-ATPase did not contribute significantly to the fall in intracellular ATP.

Similarly, disruption of the transmembrane proton gradient across the inner mitochondrial membrane might occur and result in ATP hydrolysis by the mitochondrial ATPase (23). We reasoned that, were this the case, inhibition of this enzyme with oligomycin should reduce the fall in ATP seen after $\mathrm{H}_{2} \mathrm{O}_{2}$ exposure. In fact, oligomycin-exposed cells showed a fall in ATP which was as great as seen in control cells, both with or without $\mathrm{H}_{2} \mathrm{O}_{2}$ exposure. In addition, in experiments to be reported elsewhere, we have shown that the calmodulin sensitive and insensitive $\mathrm{Ca}^{++}$-ATPase activities (investigated in red cell ghosts) are actually decreased after exposure to $\mathrm{H}_{2} \mathrm{O}_{2}(0.5-5 \mathrm{mM})$. Thus, increased activities of these ATPases are unlikely to explain the rapid decrease in intracellular ATP seen after oxidant injury. Besides the three ATPases investigated, many others exist within the cell and may contribute to ATP hydrolysis.

The results of this study may be compared with alterations 
in adenylate nucleotides in stimulated human neutrophils (30). In that cell, in the presence of glucose, stimulation results in a rapid irreversible fall in ATP without significant increases in ADP or AMP. However, in contrast to our findings, lactate production and glucose uptake were not altered.

Of interest is the contrast between our results and those obtained when endothelial cells or intact lungs are exposed to 1 atm oxygen, a setting in which cellular production of $\mathrm{O}_{\overline{2}}^{-}$may be increased (31). Rubin (32) found no significant decrease in cellular ATP content of pig aortic endothelial cells after a 24-h exposure, and Fisher (33) found no change in the whole lung adenine nucleotide content, ATP/ADP ratio, or energy charge during exposure of rats for $48 \mathrm{~h}$. These results suggest that the consequences of endothelial cell or lung damage from hyperoxic exposure may be distinct from those described in this report.

We have shown that profound ATP loss may be seen in endothelial cells, and may be produced in a cultured cell line by stimulated PMN. It will now be important to determine if there is a loss of ATP-dependent cellular functions in these cells, and if such loss contributes to the cell dysfunction and death seen after exposure to oxidants.

\section{Acknowledgments}

The authors wish to thank Dr. Gerry Boss for his assistance and critique, and Jana Glasgow for preparing the manuscript. The study was supported in part by University of California at San Diego adult respiratory failure Specialized Centers of Research grant HL-23584 from the National Institutes of Health.

\section{References}

1. Weiss, S. J., J. Young, A. F. LoBuglio, A. Slivka, and N. Nimeh. 1981. Role of hydrogen peroxide in neutrophil-mediated destruction of cultured endothelial cells. J. Clin. Invest. 68:714-721.

2. Sachk, T., C. F. Moldow, P. R. Craddock, T. K. Bowers, and H. S. Jacob. 1978. J. Clin. Invest. 61:1161-1167.

3. Clark, R. A., S. J. Klebanoff, A. B. Einstein, and A. Fefer. 1975. Peroxidase- $\mathrm{H}_{2} \mathrm{O}_{2}$-halide system: cytotoxic effect on mammalian tumor cells. Blood. 45:161-170.

4. Simon, R. H., C. H. Scoggin, and D. Patterson. 1981. Hydrogen peroxide causes the fatal injury to human fibroblasts exposed to oxygen radicals. J. Biol. Chem. 256:7181-7186.

5. Tate, R. M., K. M. VanBenthuysen, D. M. Shasby, I. F. McMurtry, and J. E. Repine. 1982. Oxygen radical mediated permeability edema and vasoconstriction in isolated perfused rabbit lungs. Am. Rev. Respir. Dis. 217:411-415.

6. Parks, D. A., G. B. Buckley, and D. N. Granger. 1983. Role of oxygen-derived free radicals in digestive tract diseases. Surgery. 94:415421.

7. Hansson, R., B. Gustafsson, O. Jonsson, S. Lundstom, S. Pettersson, T. Schersten, and J. Waldenstrom. 1982. Effect of xanthine oxidase inhibition on renal circulation after ischemia. Transplant. Proc. 14:51-58.

8. Cochrane, C. G., R. G. Spragg, and S. D. Revak. 1983. Studies on the pathogenesis of the adult respiratory distress syndrome: evidence of oxidant activity in bronchoalveolar lavage fluid. J. Clin. Invest. 71: 754-761.

9. Kellog, E. W., and I. Fridovich. 1977. Liposome oxidation and erythrocyte lysis by enzymatically generated superoxide and hydrogen perosice. J. Biol. Chem. 752:6721-6728.

10. Brawn, K., and I. Fridovich. 1981. DNA strand scission by enzymatically generated oxygen radicals. Arch. Biochem. Biophys. 206: 414-421.

11. Holmsen, H., and L. Robkin. 1977. Hydrogen peroxide lowers
ATP levels in platelets without altering adenylate energy charge and platelet function. J. Biol. Chem. 252:1752-1757.

12. Ager, A. 1982. Assessment of endothelial damage based on responses of cultured aortic endothelial cells to oxygen radicals and hydrogen peroxide. In 1st International Endothelial Cell Symposium of the ETCS, The Endothelial Cell-Pluripotent Control Cell of the Vessel Wall. Karger, Basel. 84-91.

13. Atkinson, D. E. 1977. Cellular Energy Metabolism and Its Regulation. Academic Press, Inc. New York.

14. Koren, H. S., B. S. Handwerger, and J. R. Wunderlich. 1975. Identification of macrophage-like characteristics in a cultured murine tumor line. J. Immunol. 144:894-897.

15. Busch, C., P. A. Cancilla, L. E. DeBault, J. C. Goldsmith, and W. G. Owen. 1982. Use of endothelium cultured on microcarriers as a model for the microcirculation. Lab. Invest. 47:498-504.

16. Labarca, C., and K. Paigen. 1980. A simple, rapid and sensitive DNA assay procedure. Anal. Biochem. 102:344-352.

17. Stanley, P. E., and S. G. Williams. 1969. Use of the liquid scintillation spectrometer for determining adenosine triphosphate by the luciferase enzyme. Anal. Biochem. 29:381-392.

18. Hershfield, M. S., and J. E. Seegmiller. 1976. Regulation of de novo purine biosynthesis in human lymphoblasts. J. Biol. Chem. 251: 7348-7354.

19. Khym, J. X. 1975. An analytic system for rapid separation of tissue nucleotides at low pressure on conventional anion exchangers. Clin. Chem. 21:1245-1252.

20. Pogolotti, A. L., Jr., and D. V. Santi. 1982. High pressure liquid chromatography-ultraviolet analysis of intracellular nucleotides. Anal. Biochem. 126:335-345.

21. Hyslop, P. A., and L. A. Sklar. 1984. A quantitative fluorimetric assay for the determination of oxidant production by polymorphonuclear leukocytes: its use in the simultaneous fluorimetric assay of cellular activation processes. Anal. Biochem. 141:280-286.

22. Packey, D. J., and T. Sweeney. 1981. In vivo functioning of the $\mathrm{Na}^{+}, \mathrm{K}^{+}$-activated ATPase. Curr. Top. Cell Regul. 19:152-217.

23. Thayer, W. S., and P. C. Hinkle. 1975. Synthesis of adenosine triphosphate by an artificially imposed electrochemical proton gradient in bovine heart submitochondrial particles. J. Biol. Chem. 250:53305335.

24. Test, S. T., and S. J. Weiss. 1984. Quantitative and temporal characterization of the extracellular $\mathrm{H}_{2} \mathrm{O}_{2}$ pool generated by human neutrophils. J. Biol. Chem. 259:399-405.

25. Hein, W. G., D. Appleman, and H. T. Pyfrom. 1956. Effects of 3-amino-1, 2,4-triazole (AT) on catalase and other compounds. Am. J. Physiol. 186:19-26.

26. Chapman, A. G., A. L. Miller, and D. E. Atkinson. 1976. Role of the adenylate deaminase reaction in regulation of adenine nucleotide. Metabolism in Ehrlich ascites tumor cells. Cancer Res. 36:1144-1150.

27. Donnelly, M., and I. Scheffler. 1976. Energy metabolism in respiration-deficient and wild type chinese hamster fibroblasts in culture. J. Cell. Physiol. 89:39-52.

28. Sauer, L. A. 1978. Control of adenosine monophosphate catabolism in mouse ascites tumor cells. Cancer Res. 38:1057-1063.

29. Brigelius, R. 1983. Glutathione oxidation and activation of pentose phosphate cycle during hydroperoxide metabolism. Hoppe-Seyler's Z. Physiol. Chem. 364:989-996.

30. Borrogaard, N., and T. Herlin. 1982. Energy metabolism of human neutrophils during phagocytosis. J. Clin. Invest. 70:550-557.

31. Freeman, B. A., and J. D. Crapo. 1981. Hyperoxia increases oxygen radical production in rat lungs and lung mitochondria. J. Biol. Chem. 256:10986-10992.

32. Rubin, D. B., B. Housset, Y. Jean-Mairet, and A. F. Junod. 1983. Effects of hyperoxia on biochemical indexes of pig aortic endothelial function. In Vitro. 19:625-634.

33. Fisher, A. B. 1978. Energy status of the rat lung after exposure to elevated $\mathrm{PO}_{2}$. J. Appl. Physiol.: Respir. Environ. Exercise Physiol. 45: 56-59. 